\title{
GRUP INVERSE TERKAIT MATRIKS LESLIE YANG STOKASTIK
}

\author{
Teduh Wulandari Mas'oed ${ }^{1}$, Agah D Garnadi ${ }^{1}$ \\ ${ }^{1}$ Jurusan Matematika, Fakultas MIPA, Institut Pertanian Bogor, Indonesia \\ e-mail: teduhw@gmail.com, agahga@apps.ipb.ac.id
}

Kata Kunci: Matriks Markov, Matriks Leslie, Grup Inverse.

Abstrak. Dalam tulisan ini akan dibahas mengenai definisi matriks Markov, Matriks Leslie dan Grup Inverse. Grup Inverse memainkan peran penting dalam mengungkap sifat-sifat dari Matriks Markov. Selanjutnya akah diperlihatkan hubungan antara Matriks Markov dengan Grup Inverse, hubungan ini yang akan diperumum dalam Matriks Leslie. 


\section{PENDAHULUAN}

Matriks Markov pertama kali dikembangkan oleh Andrey Markov pada awal abad ke-20. Penggunaan dari matriks stokastik ini sudah dikenal diberbagai bidang ilmiah, yaitu di dalam teori probabilistik, statistik, matematika keuangan dan aljabar linier, serta ilmu komputer dan genetika populasi. Dari suatu rantai Markov yang membentuk suatu matriks Markov, $T$, dapat diperoleh suatu grup inverse $A^{\#}$ dari matriks $A=I-T$.-Neumann menyatakan dalam [3] bahwa grup inverse ini yang akan memainkan peranan penting dalam aplikasi dari rantai Markov.

Grup Inverse dari suatu $M$-matriks dapat diaplikasikan dalam beberapa topik berikut, seperti dalam analisis konvergen dari metode iterasi bagi sistem singular, grup invers diaplikasikan dalam kondisi monoton. Grup inverse juga diaplikasikan dalam convexity and concavity of the Perron root and vector dalam model populasi dengan menghitung basis nonnegative dari ruang eigen Perron. Grup Invers juga digunakan dalam graph teori yaitu untuk menhitung konektivitas aljabar dari graf tak berarah. Selain itu aplikasi grup invers juga dapat dilihat dalam rantai Markov, yaitu untuk melihat kapan suatu keadaan kembali pada state yang telah ditentukan dan juga grup invers digunakan dalam analisis dari stabilitas komputasi suatu vektor distribusi.

Leslie Matrices digunakan untuk memodelkan pertumbuhan (dan penurunan) dari populasi yang memiliki struktur usia. Dalam model yang dinamai sesuai dengan nama penemunya yaitu Patrick H. Leslie (1945), misalkan diberikan kelas usia, dan dicatat berapa banyak orang yang berada pada kelas usia tersebut.

Kemudian, setiap periode waktu, dicatat berapa orang berpindah ke kelas usia berikutnya, atau mati. Tingkat kelangsungan hidup untuk setiap kelas usia menggambarkan proporsi populasi yang pindah ke kelas usia berikutnya. Individu baru juga dapat lahir, dan tingkat kelahiran, atau fekunditas menggambarkan tingkat per kapita kelahiran yang diperoleh dari masingmasing kategori usia.

Dengan melihat kemiripan bentuk dari matriks Markov dan matriks Leslie, memunculkan pertanyaan dapatkah matriks Leslie dilihat sebagai matriks Markov? Pertanyaan ini yang dicoba dijawab dalam tulisan ini. Lebih lanjut akan dilihat mungkinkah dibentuk grup invers dari matriks Leslie yang juga merupakan matriks Markov? Pertanyaan selanjutnya dari penelitian ini adalah dapatkah bentuk grup invers yang diperoleh dari matriks Leslie yang bersifat Markov ini diperumum untuk matriks Leslie yang umum? Dan bagian terakhir dari pertanyaan tersebut belum berhasil dijawab dalam tulisan ini.

Tulisan ini terbagi atas 4 bagian, yaitu bagian pertama bercerita tentang matriks markov/stokastik dan matriks leslie. Pada bagian kedua, tulisan ini berisikan tentang definisi grup invers dan eksistensi dari grup invers bagi matriks markov/stokastik. Bagian terakhir dari tulisan ini mengenai grup invers dari matriks leslie yang stokastik.

\section{MATRIKS MARKOV DAN MATRIKS LESLIE.}

Tulisan ini diawali dengan pembahasan mengenai definisi dari dua matriks menjadi subjek pada tulisan ini yaitu matriks Markov dan matriks leslie.

\subsection{Matriks Markov.}

Dalam matematika, matriks Markov, juga disebut matriks probabilitas, matriks transisi probabilitas, matriks transisi, matriks substitusi, ataupun matriks stokastik, yaitu matriks yang digunakan untuk mengkarakterisasi transisi untuk rantai Markov. Elemen dari matriks markov 
harus berupa bilangan real dalam interval tertutup $[0,1]$ yang mewakili probabilitas terkadang disebut sebagai nonnegatif entry.

Matriks stokastik kanan adalah matriks persegi dengan elemen bilangan real, yang masingmasing baris jika dijumlahkan sama dengan 1, sedangkan matriks stokastik kiri adalah matriks persegi dengan elemen bilangan real, yang masing-masing kolom yang jika dijumlahkan adalah sama dengan 1, dan matriks stokastik ganda adalah matriks persegi dengan elemen bilangan real nonnegatif yang setiap baris dan kolom jika dijumlahkan sama dengan 1.

Dalam pengertian yang sama, dapat didefinisikan vektor Markov (juga disebut vektor probabilitas) sebagai vektor yang elemennya adalah bilangan asli nonnegatif yang jika dijumlahkan adalah 1. Dengan demikian, setiap baris matriks Markov kanan (atau kolom dari matriks Markov kiri) adalah vektor Markov.

Suatu konvensi umum dalam literatur matematika berbahasa Inggris adalah menggunakan vektor baris Markov dan matriks Markov kanan daripada vektor kolom Markov dan matriks Markov kiri.

Lebih lanjut, himpunan $S$ yang berisikan $n \times n$ nonsingular matriks Markov atas lapangan $F$ membentuk grup atas operasi perkalian matriks. Grup ini disebut Grup Markov.

Matriks Markov menggambarkan rantai Markov $\mathbf{X}_{\mathrm{t}}$ atas ruang berhingga $S$ yang memiliki kardinalitas $\mathbf{S}$.

Jika probabilitas pindah dari $i$ ke $j$ dalam satu langkah waktu adalah $\operatorname{Pr}(j \mid i)=T_{i j}$, matriks stokastik $T$ diberikan dengan menggunakan $T_{i j}$ sebagai elemen baris ke- $i$ dan kolom ke- $j$, sebagai contoh

$$
T=\left(\begin{array}{cccccc}
T_{1,1} & T_{1,2} & \ldots & T_{1, j} & \ldots & T_{1, S} \\
T_{2,1} & T_{2,2} & \ldots & T_{2, j} & \ldots & T_{2, S} \\
\vdots & \vdots & \ddots & \vdots & \ddots & \vdots \\
T_{i, 1} & T_{i, 2} & \ldots & T_{i, j} & \ldots & T_{i, S} \\
\vdots & \vdots & \ddots & \vdots & \ddots & \vdots \\
T_{S, 1} & T_{S, 2} & \ldots & T_{S, j} & \ldots & T_{S, S}
\end{array}\right)
$$

Karena total probabilitas transisi dari state $i$ ke state lain harus 1 maka dapat diperoleh

$$
\sum_{j=1}^{S} T_{i, j}=1
$$

dengan demikian matriks ini adalah matriks stokastik kanan.

Penjumlahan setiap elemen perbaris dapat ditulis dengan $T 1=1$ dengan 1 adalah vektor berdimensi $S$ dengan setiap elemen adalah 1. Dengan menggunakan teknik ini dapat dilihat hasil dari perkalian dua matriks stokastik kanan $T^{\prime}$ dan $T^{\prime \prime}$ juga mariks stokastik kanan

$$
T^{\prime} T^{\prime \prime} 1=T^{\prime}\left(T^{\prime \prime} 1\right)=T^{\prime} 1=1
$$

Secara umum, $T^{k}$ dari matrik stokastik kanan $T$ juga merupakan matriks stokastik kanan.

Transisi probabilitas dari $i$ ke $j$ dalam dua tahap diberikan oleh elemen ke $(i, j)$ dari matriks $T$,dapat dinotasikan dengan $\left(T^{2}\right)_{i, j}$. Secara umum, transisi probabilitas dari sebarang state ke state lain dalam rantai Markov berhingga diberikan oleh matriks $T$, dalam $k$ langkah diberikan oleh $T^{k}$.

Berikut diberikan contoh dari matriks Markov. Misalkan diberikan seekor kucing, seekor tikus dan lima kotak karton yang disusun melingkar. Pada saat permainan dimulai kucing di 
kotak pertama dan tikus diletakkan di kotak kelima. Kucing dan tikus keduanya melompat ke kotak yang berdekatan secara acak selama permainan. Misalnya. jika kucing berada di kotak kedua dan tikus di kotak keempat, probabilitasnya adalah seperempat bahwa kucing akan berada di kotak pertama dan tikus di kotak kelima dilangkah selanjutnya. Jika kucing berada di kotak pertama dan tikus di kotak kelima, probabilitasnya adalah satu bahwa kucing akan berada di kotak dua dan tikus akan berada di kotak empat pada langkah selanjutnya. Kucing memakan tikus jika keduanya berakhir di kotak yang sama dan permainanpun berakhir. Variabel acak $K$ memberikan jumlah langkah waktu tikus tetap dalam permainan.

Rantai markov yang menggambarkan permainan tersebut memuat kondisi 5 state berikut berdasarkan kombinasi posisi dari kucing dan tikus. Perhatikan bahwa tikus tidak dapat memiliki index lebih kecil dari index kucing dan jumlah dari kedua indeks haruslah genap. Berikut state yang mungkin

- state $1 ;(1,3)$

- state $2 ;(1,5)$

- state $3 ;(2,4)$

- state $4 ;(3,5)$

- state 5; game over; $(2,2),(3,3)(4,4)$

Matriks Markov $T$ mewakili probabilitas transisi dari sistem tadi (baris dan kolom dalam matriks ini diindeks oleh kemungkinan keadaan yang tercantum di atas, dengan keadaan pratransisi sebagai status baris dan pasca-transisi sebagai kolom). Misalnya, dimulai dari state $1 ;(1,3)$ - baris 1 - tidak mungkin sistem tetap dalam state ini, jadi $T_{11}=0$; sistem juga tidak dapat bertransisi ke state 2 - karena kucing artinya akan tetap berada di kotak yang sama - jadi $T_{12}=0$, dan oleh argumen serupa untuk tikus $T_{14}=0$. Transisi ke state 3 atau 5 diizinkan, dengan demikian $T_{13}, T_{15} \neq 0$. Sehingga diperolehlah matriks $T$ berikut

$$
T=\left(\begin{array}{ccccc}
0 & 0 & 1 / 2 & 0 & 1 / 2 \\
0 & 0 & 1 & 0 & 0 \\
1 / 4 & 1 / 4 & 0 & 1 / 4 & 1 / 4 \\
0 & 0 & 1 / 2 & 0 & 1 / 2 \\
0 & 0 & 0 & 0 & 1
\end{array}\right)
$$

\subsection{Matriks Leslie.}

Dalam matematika terapan, matriks Leslie adalah model struktur usia dari pertumbuhan populasi yang sangat populer dalam ekologi populasi. Matriks Leslie (juga disebut model Leslie) adalah salah satu model terpercaya dalam menggambarkan pertumbuhan populasi (dan distribusi dari usia yang diproyeksikan), di mana populasi tertutup untuk migrasi, tumbuh dalam lingkungan yang tidak terbatas, dan hanya satu jenis kelamin, biasanya wanita, yang diperhitungkan.

Matriks Leslie digunakan dalam ekologi untuk memodelkan perubahan dalam populasi organisme selama periode waktu tertentu. Dalam model Leslie, populasi dibagi menjadi kelompok berdasarkan kelas usia. Pada setiap langkah waktu, populasi diwakili oleh vektor dengan 
elemen disetiap kelas usia di mana setiap elemen menunjukkan jumlah individu yang ada di kelas tersebut.

Matriks Leslie adalah matriks persegi dengan banyaknya baris dan kolom yang sama dengan elemen yang dimiliki oleh vektor populasi. Elemen ke- $(i, j)$ dalam matriks Leslie menunjukkan berapa banyak individu akan berada di kelas usia ke- $i$ pada langkah waktu selanjutnya bagi setiap individu dalam tahap $j$. Pada setiap langkah waktu, vektor populasi dikalikan dengan matriks Leslie untuk menghasilkan vektor populasi untuk langkah waktu berikutnya.

Untuk membangun matriks, beberapa informasi harus diketahui dari populasi:

- $n_{x}$, banyaknya individu $(n)$ untuk setiap kelas usia $x$

- $s_{x}$, peluang banyaknya individu yang bertahan dari kelas usia $x$ ke kelas usia $x+1$,

- $f_{x}$, fecundity, jumlah rata-rata per kapita keturunan perempuan yang mencapai $n_{0}$ kelahiran dari ibu kelas usia $x$. Lebih tepatnya, itu dapat dilihat sebagai jumlah keturunan yang diproduksi di kelas usia berikutnya $b_{x+1}$ diboboti oleh probabilitas mencapai kelas usia berikutnya, sehingga $f_{x}=s_{x} b_{x+1}$.

Dari pengamatan diperoleh bahwa $n_{0}$ pada waktu $t+1$ merupakan jumlah semua keturunan yang lahir dari dari langkah waktu sebelumnya dan organisme yang mampu bertahan hidup sampai waktu $t+1$ adalah organisme pada saat $t$ yang selamat dengan probabilitas $s_{x}$, diperoleh $n_{x+1}=s_{x} n_{x}$. Hal ini berakibat pada pembentukan presentasi matriks berikut:

$$
\left(\begin{array}{c}
n_{0} \\
n_{1} \\
\vdots \\
n_{\omega-1}
\end{array}\right)_{t+1}=\left(\begin{array}{cccccc}
f_{0} & f_{1} & f_{2} & \ldots & f_{\omega-2} & f_{\omega-1} \\
s_{0} & 0 & 0 & \ldots & 0 & 0 \\
0 & s_{1} & 0 & \ldots & 0 & 0 \\
0 & 0 & s_{3} & \ldots & 0 & 0 \\
\vdots & \vdots & \vdots & \ddots & \vdots & \vdots \\
0 & 0 & 0 & \ldots & s_{\omega-2} & 0
\end{array}\right)\left(\begin{array}{c}
n_{0} \\
n_{1} \\
\vdots \\
n_{\omega-1}
\end{array}\right)
$$

dengan $\omega$ adalah usia maksimum yang dapat dicapai dalam populasi.

Persamaan diatas dapat ditulis

$$
n_{t+1}=L n_{t} \text { atau } n_{t}=L^{t} n_{0}
$$

dengan $n_{t}$ adalah vektor populasi pada watu $t$ dan $L$ adalah matriks Leslie.

Berikut diberikan contoh dari matriks Leslie. Misalnya diberikan populasi belalang yang ingin lihat pertumbuhan populasinya. Untuk memahami bagaimana populasi tumbuh/menurun seiring waktu, perlu dilihat apa yang terjadi pada setiap tahap kehidupan belalang. Hal ini dikarenakan oleh:

- Tidak semua telur belalang bertahan hidup untuk menjadi dewasa (faktanya, masingmasing hanya $2 \%$ pertahun yang bertahan sampai tahap nymph, dan $5 \%$ dari nymph bertahan hidup hingga masa dewasa).

- Sebagian mati saat masih menjadi telur, beberapa mati sebagai nymph.

- Belalang hanya bereproduksi selama tahap dewasa dalam kehidupan mereka - rata-rata dewasa betina menghasilkan 1000 telur sebelum mati. 
- Belalang dewasa mati segera setelah reproduksi.

- Karena hanya betina yang bereproduksi, model ini hanya didasarkan pada populasi betina.

- Karena setiap tahap perkembangan memiliki kelangsungan hidup yang berbeda dan karakter reproduksi, pelacakan populasi dilakukan pada setiap tahap individual : telur, nymph, dan dewasa

- Misalkan

- $x_{1}(t)$ adalah banyaknya telur betina pada waktu $t$

- $x_{2}(t)$ adalah banyaknya nymph betina pada waktu $t$

- $x 3(t)$ adalah banyaknya belalang betina dewasa pada waktu $t$

Dinamika pertumbuhan populasi belalang dapat dilihat dalam persamaan berikut ini

- Misalkan setiap betina dewas akan memproduksi, rata-ratam 1000 telur setiap tahun, model ini dapat dibentuk persamaan

$$
x_{1}(t+1)=1000 x_{3}(t)
$$

- $2 \%$ dari telur akan tumbuh menjadi nymphs, persamaan yang dapat diperoleh

$$
x_{2}(t+1)=.02 x_{1}(t)
$$

- 5\% dari nymphs akan tumbuh dewasa, dimodelkan dalam bentuk

$$
x_{3}(t+1)=.05 x_{2}(t)
$$

Kombinasi dari ketiga persamaan tersebut menjadi

$$
\begin{aligned}
\left(\begin{array}{l}
x_{1}(t+1) \\
x_{2}(t+1) \\
x_{3}(t+1)
\end{array}\right) & =\left(\begin{array}{ccc}
0 & 0 & 1000 \\
0.02 & 0 & 0 \\
0 & 0.05 & 0
\end{array}\right)\left(\begin{array}{l}
x_{1}(t) \\
x_{2}(t) \\
x_{3}(t)
\end{array}\right) \\
n_{t+1} & =L n_{t}
\end{aligned}
$$

\section{GRUP INVERS MATRIKS MARKOV.}

Bagian kedua dari pembahasan tulisan ini adalah mengenai definisi dari grup invers dan eksistensi dari grup invers bagi matriks Markov.

\subsection{Definisi Grup Invers.}

Misalkan $A \in F^{m \times m}$,grup inverse dari $A$, jika ia ada, didefinisikan oleh matriks $A^{\sharp}$ yang memenuhi kondisi

$$
\begin{aligned}
A A^{\sharp} A & =A \\
A^{\sharp} A A^{\sharp} & =A^{\sharp} \\
A A^{\sharp} & =A^{\sharp} A
\end{aligned}
$$


Untuk $A \in F^{m \times m}$, dapat ditunjukkan bahwa ketiga persamaan diatas memiliki penyelesaian jika dan hanya jika $\operatorname{rank}(A)=\operatorname{rank}\left(A^{\sharp}\right)$, selanjutnya jika penyelesaian itu ada, maka penyelesaian tersebut adalah penyelesaian tunggal. Penggunaan kata "grup inverse" didasarkan pada jika $A \in F^{m \times m}$ sedemikian sehingga $\operatorname{rank}(A)=\operatorname{rank}\left(A^{\sharp}\right)$, maka $A$ adalah anggota himpunan $G \subseteq F^{m \times m}$ sedemikian sehingga $G$ membentuk grup terhadap operasi perkalian standar yang kita kenal. Akibatnya $A$ memiliki invers dalam operasi perkalian dan invers perkalian dari $A$ adalah $A^{\sharp}$.

Misalkan diberikan matriks $A$ berikut

$$
A=\left(\begin{array}{cccc}
1 & -1 & 0 & 0 \\
-\frac{1}{2} & 1 & -\frac{1}{2} & 0 \\
0 & -\frac{1}{2} & 1 & -\frac{1}{2} \\
0 & 0 & -1 & 1
\end{array}\right)
$$

Pilih

$$
A^{\sharp}=(I-T)^{\sharp}=\frac{1}{36}\left(\begin{array}{cccc}
35 & 10 & -26 & -19 \\
5 & 22 & -14 & -13 \\
-13 & -14 & 22 & 5 \\
-19 & -26 & 10 & 35
\end{array}\right)
$$

Dapat ditunjukkan bahwa $A^{\sharp}$ membentuk grup invers bagi $A$.

\subsection{Eksistensi Grup Invers Matriks Markov.}

Berdasasrkan tulisan Meyer pada [1] yang menyatakan bahwa untuk setiap matriks transisi $T$, ada grup inverse $A^{\sharp}$ dari $A$ dengan $A=I-T$. Dari teorema tersebut dapat diambil kesimpulan bahwa setiap matriks transisi akan memiliki grup inverse.

Misalkan diberikan matriks transisi, $T$, berikut

$$
T=\left(\begin{array}{cccc}
0 & 1 & 0 & 0 \\
\frac{1}{2} & 0 & \frac{1}{2} & 0 \\
0 & \frac{1}{2} & 0 & \frac{1}{2} \\
0 & 0 & 1 & 0
\end{array}\right)
$$

maka dapat diperoleh

$$
A=(I-T)=\left(\begin{array}{llll}
1 & 0 & 0 & 0 \\
0 & 1 & 0 & 0 \\
0 & 0 & 1 & 0 \\
0 & 0 & 0 & 1
\end{array}\right)-\left(\begin{array}{llll}
0 & 1 & 0 & 0 \\
\frac{1}{2} & 0 & \frac{1}{2} & 0 \\
0 & \frac{1}{2} & 0 & \frac{1}{2} \\
0 & 0 & 1 & 0
\end{array}\right)=\left(\begin{array}{cccc}
1 & -1 & 0 & 0 \\
-\frac{1}{2} & 1 & -\frac{1}{2} & 0 \\
0 & -\frac{1}{2} & 1 & -\frac{1}{2} \\
0 & 0 & -1 & 1
\end{array}\right)
$$

Sehingga

$$
A^{\sharp}=(I-T)^{\sharp}=\frac{1}{36}\left(\begin{array}{cccc}
35 & 10 & -26 & -19 \\
5 & 22 & -14 & -13 \\
-13 & -14 & 22 & 5 \\
-19 & -26 & 10 & 35
\end{array}\right)
$$

membentuk grup invers bagi $A$. 


\section{GRUP INVERS MATRIKS LESLIE YANG STOKASTIK.}

Pada bagian ketiga ini, akan dilihat grup invers dari matriks Leslie yang stokastik. Sebelum mendefinisikan matrik Leslie yang stokastik diberikan kembali definisi matriks Leslie. Matriks Leslie adalah matriks yang berbentuk

$$
\left(\begin{array}{c}
n_{0} \\
n_{1} \\
\vdots \\
n_{\omega-1}
\end{array}\right)_{t+1}=\left(\begin{array}{cccccc}
f_{0} & f_{1} & f_{2} & \ldots & f_{\omega-2} & f_{\omega-1} \\
s_{0} & 0 & 0 & \ldots & 0 & 0 \\
0 & s_{1} & 0 & \ldots & 0 & 0 \\
0 & 0 & s_{3} & \ldots & 0 & 0 \\
\vdots & \vdots & \vdots & \ddots & \vdots & \vdots \\
0 & 0 & 0 & \ldots & s_{\omega-2} & 0
\end{array}\right)\left(\begin{array}{c}
n_{0} \\
n_{1} \\
\vdots \\
n_{\omega-1}
\end{array}\right)
$$

dengan nilai setiap elemennya nonnegatif bilangan real. Jika diperoleh matriks Leslie yang memenuhi kriteria matriks Markov yaitu matriks yang setiap elemennya nonnegatif real yang kurang dari satu dan setiap baris jumlah elemennya adalah satu maka matriks Leslie yang kita peroleh adalah matriks Leslie yang bersifat Markov yang kita sebut matriks Leslie yang stokastik.

Jika kita memiliki matriks Leslie yang stokastik, artinya matriks tersebut memenuhi syarat sebagai matriks Markov, berdasarkan hasil dari bagian sebelumnya matrik transisi atau matriks stokastik pasti memiliki memiliki grup invers. Sehingga dapat disimpulkan bahwa setiap matriks Leslie yang stokastik, maka $(I-L)$ memiliki grup inverse.

\section{UCAPAN TERIMA KASIH.}

Terima kasih kepada Pof. Dr. Pudji Astuti dan Dr. Indah Wijayanti atas masukannya.

\section{KESIMPULAN}

Dari hasil pembahasan diatas dapat diperoleh matriks Leslie yang memenuhi kriteria matriks Markov. Setiap matriks Leslie yang memenuhi kriteria matriks Markov disebut matriks Leslie yang stokastik. Selain itu diperoleh juga bahwa setiap matriks Markov $T$ akan memiliki grup inverse $A^{\sharp}$ untuk suatu matriks $A=I-T$. Akibatnya dapat diperoleh bahwa setiap matriks Leslie yang stokastik pastilah $(I-L)$ memiliki grup inverse.

Penelitian ini dapat dilanjutkan dengan pertanyaan selanjutnya yaitu dapatkah bentuk grup invers yang diperoleh dari matriks Leslie yang stokastik ini diperumum untuk matriks Leslie yang umum?

\section{REFERENCES}

[1] Meyer Jr, CD. The Role of The Group Generalized Inverse In The Theory of Finite Markov Chains. Siam Review. 17(443-464). 1975.

[2] Kirkland, S.J. Neumann, M. Group inverses of M-matrices and their applications. London, CRC Press. 2013.

[3] Neumann, M. Group Inverses of Singular M-matrices and Applications. Presentation at Novi Sad. 2010.

[4] Israel B, Lecture 6:The Group Inverse, [internet] (diunduh pada 21 juni 2018) Tersedia pada : http://benisrael.net/GI-LECTURE-6.pdf 
[5] Ellner, SP. Chapter 5 : Structured populations: discrete time, [internet] (diunduh pada 21 juni 2018) Tersedia pada : http://www.eeb.cornell.edu/Ellner/lte/Chapter5.pdf 